\title{
Effect of composts produced from vegetable waste and/or manure on lettuce crop and their antioxidants content
}

\section{Efecto de compostas elaboradas con residuos vegetales y/o estiércol en el cultivo de lechuga y su contenido de antioxidantes}

Aida Solís-Oba ${ }^{1}$, Joseph I. Hernández-Rivadeneyra², Rigoberto Castro-Rivera², Norberto Manjarrez ${ }^{1}$, Myrna Solís-Oba ${ }^{2 *}$

${ }^{1}$ Universidad Autónoma Metropolitana, Unidad Xochimilco, Ciudad de México, Mexico.

${ }^{2}$ Instituto Politécnico Nacional, Centro de Investigación en Biotecnología Aplicada, Tlaxcala, Mexico.

${ }^{*}$ Corresponding author

E-mail address: myrobat|x@yahoo.com.mx (M. Solís-Oba)

Article history:

Received: 15 January 2020 / Received in revised form: 9 April 2020 / Accepted: 21 April 2020 / Published online: 4 May 2020.

https://doi.org/10.29267/mxib.2020.5.2.86

\begin{abstract}
Currently one of the most important problems in the world is the erosion and the low productivity of the agriculture soils, so a common practice to increase yield is to use mineral fertilizers; however excessive use cause environmental problems. The application of composts based on organic wastes is a sustainable way to reduce soil pollution and increase their fertility. The aim of this work was to evaluate the compost effect made from different combinations of vegetable waste and cow manure on the yield and antioxidant content of a lettuce crop, and its comparison with two controls: chemical fertilizers (Chem) and without fertilization (C-). Four types of composts were prepared using vegetable waste $(\mathrm{V})$, stubble (S), cow manure (M) and the mixture of vegetable and cow manure (MV), the fertilization rate was 5 and $10 \%$. The variables evaluated were plant height, number of leaves, foliage volume, and antioxidants content. Composts $\mathrm{V}$ and $\mathrm{S}$ registered greater height $(p>0.05)$ than the rest of the treatments and controls. There were no differences $(p>0.05)$ in antioxidant content between
\end{abstract}


treatments and controls; however, the composts promoted higher values of DPPH and polyphenol content with respect to C-. The results obtained in the evaluated variables were due materials used for composting, were better with those made with vegetable waste. Composting vegetable residues and animal manure is a good alternative to diminish use of mineral fertilizers and the need of disposing these organic material, since the composts improved the lettuce properties compared to C-.

Keywords: antioxidants, compost, lettuce, waste, yield

\section{RESUMEN}

Actualmente uno de los problemas más importante en el mundo es la erosión y la baja productividad de los suelos agrícolas, por ello una práctica común para incrementar la productividad es usar fertilizantes minerales; sin embargo su uso excesivo ocasiona problemas ambientales. La aplicación de compostas a base de residuos orgánicos es una manera sustentable para reducir la contaminación e incrementar la fertilidad de los suelos. El objetivo fue evaluar el efecto de compostas elaboradas con residuos vegetales y estiércol de vaca, sobre el rendimiento y contenido de antioxidantes en cultivo de lechuga, y su comparación con: fertilizante mineral (Chem) y sin fertilización (C-). Se elaboraron 4 compostas, residuos vegetales (V), rastrojo (S), estiércol de vaca (M) y la mezcla de residuos vegetales y estiércol (MV), la dosis fue 5 y $10 \%$. Las variables evaluadas fueron altura de la planta, número de hojas, volumen del follaje y contenido de antioxidantes. Las compostas $\mathrm{V}$ y $S$ registraron mayor altura $(p>0.05)$ que el resto de los tratamientos y los controles. No se evidenciaron diferencias $(p>0.05)$ en el contenido de antioxidantes entre tratamientos; las compostas promovieron mayores valores de DPPH y contenido de polifenoles con respecto a C-. Los resultados obtenidos se deben a los materiales usados para el compostaje, siendo mejores las elaboradas con residuos vegetales. Las compostas de residuos vegetales y estiércol son una buena alternativa para disminuir el uso de fertilizantes minerales y la necesidad de disponer de esos materiales orgánicos, ya que las compostas incrementaron las propiedades de las lechugas comparadas con C-.

Palabras clave: antioxidantes, composta, lechuga, rendimiento, residuos,

\section{INTRODUCTION}

Agricultural land has suffered a significant deterioration due, among others, to population growth that demands greater amounts of food and to the intensification of agricultural production systems. Usually, in agricultural production, the soil is subjected to intense tillage, mechanical compression and the addition to harmful mineral fertilizers. Mineralizing and compacting the substrate cause loss of 
nutrients and changes in the physical properties of the soil, resulting in decreased availability of water and air for the roots, as well as a suppression of microbial processes. Although these fertilizers provide essential minerals for crops, and that is immediately available to promote their rapid growth, they do not improve soil properties or replace organic matter that is lost during cultivation, so its continued use has damaged soil productivity (Pimentel \& Burgess, 2013).

In recent decades, one of the most important problems in Mexico is the loss of productivity and biodiversity of agricultural land, due to soil degradation. Tlaxcala occupies the first place in Mexico in this area, because has retained $17 \%$ of its natural vegetation; the deterioration of the soil is approximately $72 \%$ of the surface of its territory, which implies the loss of food and water security, as well as population migration (Bolaños et al., 2016).

To recover the fertility of the land, current agricultural systems must include environmentally friendly and sustainable production systems without neglecting production increases. Some proposals include the use of organic fertilizers such as compost, vermicompost, and digestate; organic fertilizers provide nutrients for plants, help to reduce the effect of pests and diseases, maintain and improve soil structure and increase moisture retention capacity (Wilson \& Taylor, 2016). The use of organic fertilizers for a long period of time improves productivity and soil quality. Another advantage is that organic fertilizers can be made from both vegetable and animal waste since these materials have a high nutrient content. In all human communities, organic waste is generated, and if the management and disposal of these are not carried out properly, they will generate significant environmental problems, so the production of organic fertilizers with these materials helps to avoid or reduce these environmental problems (Onwosi et al., 2017). In addition some authors indicate that the risk for contamination with pesticide residues is lower among organic than conventional products (Santos et al., 2016).

On the other hand, Pandey \& Rizvi, (2009) reported that fruits and vegetables provide several compounds, such as antioxidants, that help to protect and prevent degenerative diseases. Antioxidants are secondary metabolites, like flavonoids, polyphenols, carotenoids, folic acid, ascorbic acid, tocopherols, etc. (Majewska et al., 2011). Antioxidants are important because they react with free radicals (Cui et al., 2004) that take place in biological systems, these are the cause of degenerative disorders such as mutagenesis, carcinogenesis, cardiovascular problems and aging (Majewska et al., 2011).

The most important antioxidants for human nutrition, are flavonoids and polyphenols, that are found in fruits, vegetables, cereals and beverages (Pandey \& Rizvi, 2009). The consume of lettuce has been considered healthy because is a good source of minerals, ascorbic acid, fibber, vitamins $A, C$ and $K$ and antioxidants, mainly polyphenols, flavonoids and tocopherols (Llorach \& MartínezSánchez, 2008). Nicolle et al. (2004) found that a regular intake of lettuce antioxidants prevents lipid peroxidation in tissues. Therefore, it is important to 
increase the production of these compounds in vegetables such as lettuce, it has been observed that their cultivation in soil fertilized with organic fertilizers, can be a strategy to maximize the level of bioactive molecules (Santos et al., 2016).

The aim of this work was to compare the effect of four composts made with vegetable $y / 0$ animal waste, applied in a lettuce crop to compare the growth of the plants and their antioxidant content, to determine the differences by the kind of residue used for composting.

\section{MATERIALS AND METHODS}

\subsection{Materials}

Four composts were prepared using vegetable waste and animal manure widely produced in the region; these are usually deposited in the open, causing environmental problems. The materials used to prepare the composts were: a) vegetable waste, consisting mainly of lettuce leaves, cauliflower leaves, and thorns cactus, obtained from the local market of San Martín Texmelucan, Puebla, Mexico; b) dairy cow manure obtained from a small farm in Tepetitla de Lardizábal, Tlaxcala, Mexico; c) corn stubble obtained from Tepetitla de Lardizábal, Tlaxcala, Mexico. The soil used as substrate was obtained, mixed and homogenized from the first $20 \mathrm{~cm}$ (Santos et al., 2014) of an agricultural plot adjacent to the Centro de Investigación en Biotecnología Aplicada, located in Tepetitla de Lardizábal, Tlaxcala, Mexico.

\subsection{Composting}

Four composts were prepared, the first with the vegetable waste $(\mathrm{V})$, the second with cow manure $(\mathrm{M})$, the third with $80: 20$ cow manure: vegetable mixture (MV), and the last with corn stubble (S). Additionally, to prepare all the composts, $4 \%$ by weight of corn stubble was added, to avoid compacting the materials and favoring the aeration during the composting process. The composting mixes had a $\mathrm{C} / \mathrm{N}$ ratio between 20/1 and 30/1, their initial $\mathrm{pH}$ was between 7 and 8 . The supplies were accommodated in piles, interposing the stubble, the dimensions of the piles were one meter high, for one meter wide and one meter long. The piles were mechanically aerated and moistened every week to maintain a humidity percentage between 45 and 60\% (NMX-AA-180-SCFI-2018). The composting process continued until the temperature stabilization was observed, for about six months. At the end of this time, the material was homogenized, dried in the shade and screened in $0.2 \times 0.2 \mathrm{~cm}$ meshes.

\subsection{Composts and soil analysis}

Composts and soil were analyzed by determining their $\mathrm{pH}$, electrical conductivity, $\mathrm{N}$ and $\mathrm{P}$ content, following the methods for fertility assay of Mexican standard NOM-021-SEMARNAT-2000 (NOM-021-SEMARNAT-2000), modified in quantities used for $\mathrm{N}$ and $\mathrm{P}$ content in compost: using $1 \mathrm{~g}$ compost for $\mathrm{N}$ determination and 
$0.5 \mathrm{~g}$ compost for $\mathrm{P}$ quantification. The potassium content, according to the methodology of Ruiz et al. (2010) and the germination index, calculated by using lettuce seeds according to the methodology of Tiquia \& Tam (1998). Physicochemical parameters for soil were compared with NOM-021-SEMARNAT2000 considering the values recommended for medium range fertility, and those for composts were compared with NADF-020-AMBT-2011.

\subsection{Lettuce cultivation}

Two kilograms of soil mixed with 5 and $10 \%$ weight of each compost, were placed in black polyethylene bags, in each bag a two weeks germinated lettuce seedling was sown, 15 plants were used for treatment. The experiment was carried out under a completely random design. The negative control (C-) consisted of soil without any fertilizer, the positive control (Chem) consisted of soil fertilized with urea, it was applied at 15 and 30 days after transplantation, adding $1.2 \mathrm{~g}$ urea per bag (250 kg/ha), according to Ullúa et al. (2016). The experiment was carried out in spring 2017, under greenhouse condition located in Tepetitla de Lardizábal, Tlaxcala, Mexico $19^{\circ} 15^{\prime} 59^{\prime \prime} \mathrm{N}, 98^{\circ} 22^{\prime} 38^{\prime \prime} \mathrm{W}$. The lettuces were kept in the greenhouse for two months and irrigated every third day. Weekly from week 3 to week 8 of the transplant, the height was measured with a graduated ruler, from the base of the soil to the apex of the highest leave and was counted the number of leaves. The growth rate was calculated as the slope of the height vs. time graph. To calculate the foliage volume was measured the upper diameter of the foliage with a graduated ruler, and then applying the formula to calculate the volume of a cone:

$V=\frac{1}{3} \pi r^{2} \mathrm{~h}$

At week 8 of transplant, the plants were extracted and measured the leaf area with a LI-COR brand leaf area integrator model LI-3100, and the fresh and dry weight of the aerial part were determined.

\subsection{Antioxidant content assay}

The antioxidant content in the lettuce leaves was evaluated at weeks 6 and 8 after transplantation, three leaves were taken from each plant, one from the outside, another from the middle and the last from the inside; they were dried at room temperature during 10 days (Valenzuela et al., 2019) and ground, one gram of material was taken to mix with $20 \mathrm{~mL}$ of methanol, centrifuged at $500 \mathrm{rpm}$ during 5 min, and the supernatant (methanolic extract) was used for antioxidant determinations:

DPPH. $500 \mu \mathrm{L}$ of the methanolic extract were mixed with $1 \mathrm{~mL}$ methanol and 150 $\mu \mathrm{L}$ of 2,2-diphenyl-1-picrilhydrazil (DPPH), the mixture was incubated in the dark for $45 \mathrm{~min}$, then the color change was measured at $517 \mathrm{~nm}$ with a UV-Vis 
spectrophotometer. The stability of DPPH was determined with a calibration curve using trolox as standard (Hartwik et al., 2012).

Total polyphenols. $250 \mu \mathrm{L}$ of the methanolic extract were mixed with $2.25 \mathrm{~mL}$ water, $100 \mu \mathrm{L}$ Folin-Ciocalteau reagent and $250 \mu \mathrm{L}$ of $\mathrm{Na}_{2} \mathrm{CO}_{3}$ saturated solution. The mixture was stirred in vortex and incubated for one hour at room temperature, the color change was measured with a spectrophotometer at $760 \mathrm{~nm}$. The concentration of polyphenols was calculated as equivalents of gallic acid with a standard curve, according to García et al. (2015).

Flavonoids. $100 \mu \mathrm{L}$ of the methanolic extract were mixed with $1.25 \mathrm{~mL}$ of water, $75 \mu \mathrm{L}$ of $5 \% \mathrm{NaNO}_{2}$, the mixture stood for 6 minutes at room temperature, and then $150 \mu \mathrm{L}$ of $10 \% \mathrm{AlCl}_{3}$ was added; after $5 \mathrm{~min} 500 \mu \mathrm{L}$ of $1 \mathrm{M} \mathrm{NaOH}$ was added. The color change was measured with a spectrophotometer at $510 \mathrm{~nm}$, the flavonoid content was determined with a standard routine curve, according to Floegel et al. (2011).

Dendogram. The graph of a cluster classification analysis was performed by hierarchical clustering, by the method of inter-linkage groups and measurement intervals Euclidean squared by JMP Pro. Ver. 13 software for Windows, considering all variables evaluated in this work.

\subsection{Statistical analysis}

The data obtained was ordered weekly for the variables height, volume and number of leaves, all variables were analyzed statistically using the SAS software ver 9.0, under a completely randomized design. The means test was applied using the LSD test at a confidence level of $p<0.05$, Pearson's bi-varied correlations were made with the vegetative variables and antioxidant content $p<0.05$, using the JMP Pro 13.0 software. A hierarchical cluster was also made, to see the similarities between treatments, by the closest neighbor method.

\section{RESULTS}

\subsection{Physicochemical properties of soil and composts}

The soil used in this study was sandy, the physicochemical properties of soil are shown in Table 1, which were compared with the parameters from the medium range of fertility soils from the Mexican Standard NOM-021- SEMARNAT-2000. 
Table 1. Physicochemical analysis of the soil used and comparison with the specification for medium soil fertility.

\begin{tabular}{llc}
\hline Parameter & Soil & \multicolumn{2}{c}{$\begin{array}{c}\text { Specifications for medium } \\
\text { soil fertility } \\
\text { (NOM-021- } \\
\text { SEMARNAT-2000) }\end{array}$} \\
\hline $\mathbf{p H}$ & & \\
Bulk density $\left(\mathbf{g ~ c m}^{-3}\right)$ & 1.52 & $6.6-7.3$ \\
Organic matter $(\%)$ & 0.5 & $1-1.32$ \\
Inorganic $\mathbf{~}(\mathbf{m g} / \mathbf{k g})$ & 1 & $1.6-3.5$ \\
Usable $\mathbf{P}(\mathbf{m g} / \mathbf{k g})$ & 0.16 & $20-40$ \\
$\mathbf{E C ~}(\mathbf{d S} / \mathbf{m})$ & 0.3 & $5.5-11$ \\
\hline
\end{tabular}

From the results in Table 1, it can be concluded that the soil was slightly alkaline and the presence of salts is low. The soil was poor because the content of the necessary macronutrients was much lower than the specified in the NOM-021SEMARNAT-2000.

Table 2 shows the physicochemical properties of composts, as well as the values recommended in Mexican Standard NADF-020-AMBT-2011. All composts were alkaline, their electrical conductivity and $\mathrm{N}$ content were according to the norm; however they were poor in $\mathrm{P}$ and $\mathrm{K}$. The $\mathrm{Gl}$ of the four composts prepared was between 103 and $131 \%$, values in agreement with mature composts. According Tiquia \& Tam (1998), a Gl $>80 \%$ indicates that the compost is mature and does not present phytotoxic substances or are in very small quantities, and $\mathrm{Gl}>120 \%$ indicates that the compost contains substances that promote plant growth.

Table 2. Analysis of the composts and values recommended in the Mexican Norm NADP-020-AMBT-2011.

\begin{tabular}{cccccc}
\hline Parameters & \multicolumn{4}{c}{ Composts } & \multicolumn{2}{c}{ NADF-020- } \\
& $\mathrm{V}$ & $\mathrm{S}$ & $\mathrm{MV}$ & $\mathrm{M}$ & AMBT-2011 \\
\hline $\mathbf{p H}$ & $9.0 \pm 0.1$ & $8.0 \pm 0.05$ & $9.3 \pm 0.2$ & $9.4 \pm 0.1$ & $6.5-8$ \\
$\mathbf{E C ~ ( d S / m ) ~}$ & $3.4 \pm 0.02$ & $2.3 \pm 0.05$ & $3.8 \pm 0.06$ & $4.0 \pm 0.06$ & $<8$ \\
$\mathbf{G l}(\%)$ & $114.8 \pm 1.9$ & $131.3 \pm 1.7$ & $103.4 \pm 1.5$ & $106.9 \pm 1.2$ & $\geq 75 \%$ \\
$\mathbf{C}(\%)$ & $11.4 \pm 0.34$ & $21.7 \pm 0.18$ & $18.0 \pm 0.64$ & $18.8 \pm 0.46$ & $>20 \%$ \\
$\mathbf{N}(\%)$ & $1 \pm 0.01$ & $1.5 \pm 0.01$ & $1.4 \pm 0.008$ & $1.5 \pm 0.01$ & $1-3 \%$ each \\
$\mathbf{~ K ~ ( \% ) ~}$ & $0.18 \pm 0.01$ & $0.20 \pm 0.01$ & $0.27 \pm 0.01$ & $0.27 \pm 0.01$ \\
$\mathbf{P}(\%)$ & $0.3 \pm 0.005$ & $0.4 \pm 0.005$ & $0.6 \pm 0.004$ & $0.2 \pm 0.004$ \\
& & & & &
\end{tabular}

The type of waste used for composting is an important factor that will determine the final properties of the composts. Composts prepared with vegetable waste ( $\mathrm{S}$ and $\mathrm{V}$ ) had lower values of $\mathrm{pH}, \mathrm{EC}$, the content of $\mathrm{K}$ and higher values of $\mathrm{Gl}$, compared 
with the composts using mainly cow manure (M, MV). The compost prepared only with corn stubble (S), had the highest content of organic matter, compared to the others and was the less alkaline and closer to the norm, also showed a higher content of $\mathrm{C}, \mathrm{N}$, and $\mathrm{P}$, in addition to the highest $\mathrm{Gl}$, that is, it was the richest nutrient compost.

\subsection{Lettuce cultivation}

Height, volume and number of leaves. In Figure 1 can be observed that all composts favored the growth of lettuce with respect to a negative control (C-). In week 8 they were higher between 5 and $66 \%$ compared to C-. Except with M5, using composts plants were from 2 to $25 \%$ higher than using urea. The highest heights were reached using 5 or $10 \%$ of compost $S$, these were $25 \%$ larger than using urea and $65 \%$ higher than in C-.

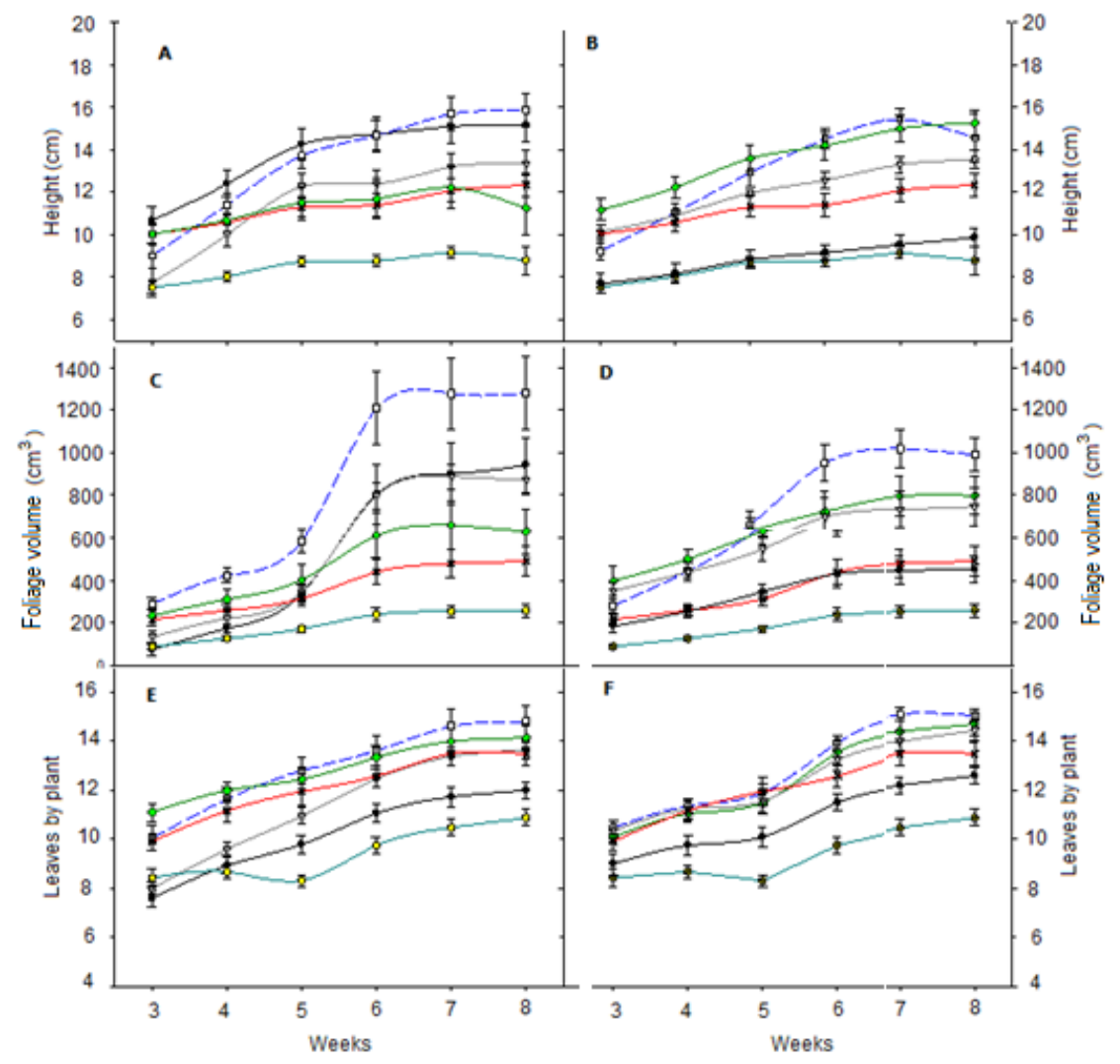

Fig. 1. Weekly evaluation of the height, foliage volume and number of lettuce leaves using composts $\mathrm{M}\left(-^{-}\right)$, MV $\left(\nabla^{-}\right), \mathrm{S}(-\square-), \mathrm{V}\left({ }^{-}\right)$Chem $(*)$, and $\mathrm{C}-\left({ }^{-}\right)$. At $5 \%$ compost (A, C, E), and $10 \%$ compost (B, D, F).

$\mathrm{n}=15$, averages \pm standard deviation

From week 3 to week 5, the growth rate was higher in the presence of composts S5, S10, M10 or MV10 than with the other treatments and controls; after week 5 the growth rate decreased, it was assumed that at the beginning composts provided more nutrients or were more available. The growth rate in the presence of 
Chem had no changes from week 3 to week 8 , and the corresponding to $C$ diminished during the last week.

In the case of the foliage volume, all composts favored the growth of plants with respect to C-, exceeding by 70 to $670 \%$. Likewise, the foliage volumes were higher by 20 to $200 \%$ than Chem, except with M5 (Fig. 1). With S10 and S5, the foliage volumes were the largest. In Figure 1 it is observed that at week 8 the foliage volume of S10, V5, M10, MV5, and C- decreased with respect to week 6, probably because they began to wilt.

Similar to the previous parameters, the number of leaves using all composts was greater than with C- (Fig. 1). The highest number of leaves at the end of the crop cycle was obtained with S5 and M10. The increase in the number of leaves of plants that were fertilized with composts or urea was in an average of one leaf weekly, while in C- number of leaves did not increase from week 3 to week 5.

Figure 1 shows that all composts improved the nutritional quality of the soil, rising heights, foliage volume and the number of leaves compared with $\mathrm{C}-$, and Chem, except with M5. From weeks 3 to week 5, the height, foliage volume and the number of leaves in the presence of Chem were of the highest, however, at the end of the experiment (weeks 7 to week 8 ) these parameters decreased compared with using composts; this can be explained because urea usually increases the development in short periods of time but at longer time organic carbon decreases and plant growth decreases (Li et al., 2017).

\subsection{Lettuce biomass}

Figure 2 shows that the fresh and dry weights of the aerial part, as well as the leaf area per lettuce with all composts, except M5 were statistically ( $p>0.05)$ higher than C- and except with M5 and M10, were statistically ( $p>0.05$ ) higher than Chem. The biomass increased was from 100 to $310 \%$ higher than C-. and from 170 to $230 \%$ higher than Chem. The values were higher using S and V at both compost content than using $\mathrm{M}$ and MV. The highest weights were with compost $S 10$ ( $p>0.05$ ), this can be explained because with this compost lettuces had more and highest leaves.

The results of the foliar area by plant were similar to the weights; values were statistically ( $p>0.05)$ higher than C- and were statistically ( $p>0.05)$ higher than Chem. M5 and M10 also were the exception. The foliar area was 80 to $280 \%$ higher using composts than C-, and 20 to $150 \%$ more than Chem. 


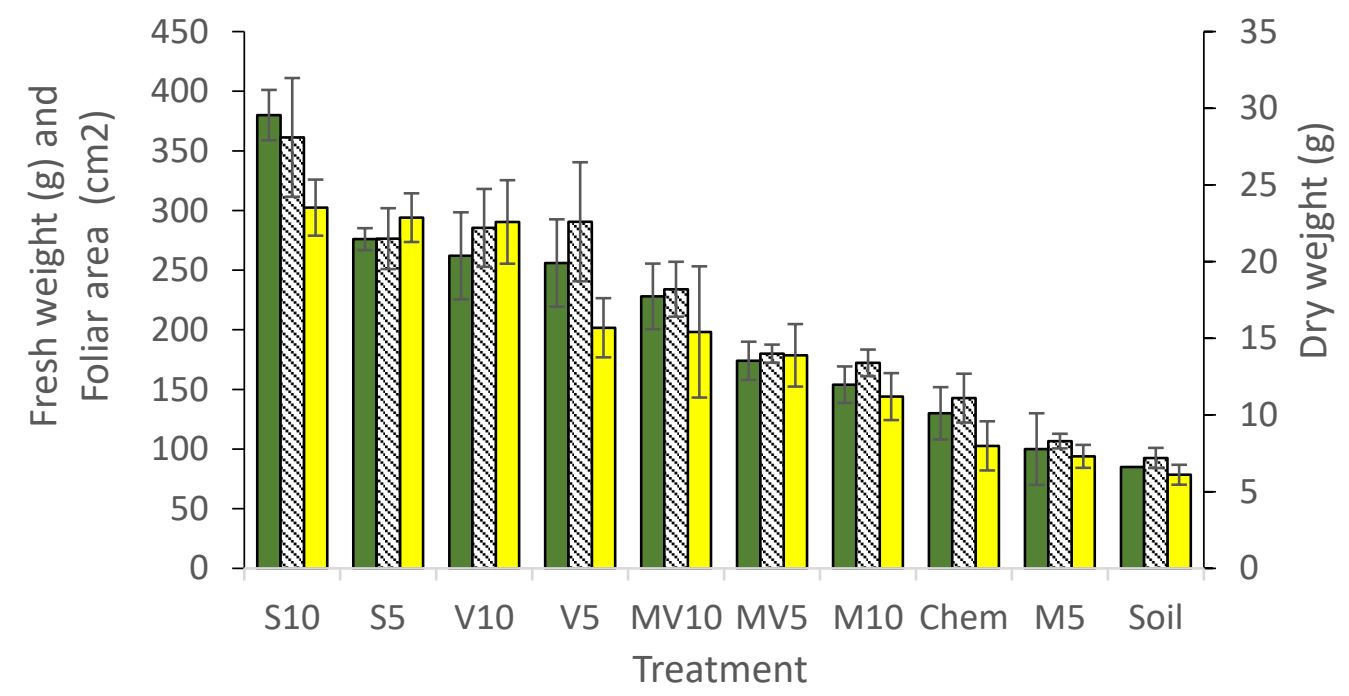

Fig. 2. Fresh weight leaf $(\square)$, foliar area ( $\square$ ) and Dry weight leaf ( at week 8 after transplantation using composts S, V, M and MV at 5 and $10 \%$ and both controls Soil and Chem.

$\mathrm{n}=15$, averages \pm standard deviation

\subsection{Antioxidants}

The results of the quantification of the antioxidants in the lettuces grown in the presence of composts and controls are in table 3.

DPPH. At week 6, the highest values were found in Chem, V10, and C-, Chem values were from 20 to $80 \%$ higher than applying other composts, whereas the DPPH in lettuces without fertilization (C-) was higher than in the presence of compost between 33 and 74\%. At week 8, except V5 and S10, DPPH content was higher with the rest of the treatments than C-. With M, MV, and S10 the content of antioxidants were equal to Chem. The highest value was recorded for V5. The DPPH increased from week 6 to week 8, except for both controls (Chem and C-) and compost $\mathrm{V} 10$.

Flavonoids. At week 6, flavonoids content in V10 was statistically equal $(p<0.05)$ to Chem, with the other composts this parameter was between 20 to $80 \%$ lower than Chem. Flavonoids content of lettuce measured in C- was equal compared with the other composts, except M5. At week 8, flavonoids content was similar between Chem and V5, with the other composts were lower between 12 to $45 \%$ than Chem. The flavonoids content was similar between lettuces from C- and the other composts, Considering C- the other composts has an equal amount of flavonoids, except S5 and V10, that had the lowest values. Ismaiel et al. (2016) reported that flavonoids production may be linked to the $\mathrm{pH}$ of the substrates, $\mathrm{pH}$ between 8.5 and 10 favor the antioxidant activity of some plants such as chard. 
Polyphenols. During week 6, as in DPPH, the higher polyphenol contents were registered with V10 and both controls. At week 8, using S10, V5, MV10, and M10 polyphenols were statistically equal than Chem and higher from 20 to $70 \%$ than C-. S5 and V10 have lower polyphenols than C-. An increase from week 6 to week 8 was observed in the polyphenol content with all composts and both controls, except for V10.

Table 3. Antioxidants measured in lettuces at week 6 and week 8 after transplantation.

\begin{tabular}{lcccccc}
\hline & \multicolumn{2}{c}{ DPPH (\%) } & \multicolumn{2}{c}{ Flavonoids $^{(\mathbf{a})}$} & \multicolumn{2}{c}{ Polyphenols $^{(\mathbf{b})}$} \\
\hline Compost & \multicolumn{2}{c}{ Weeks } & \multicolumn{2}{c}{ Weeks } & \multicolumn{2}{c}{ Weeks } \\
& 6 & 8 & 6 & 8 & 6 & 8 \\
\hline S10 & $23.3 \mathrm{~d}$ & $61.5 \mathrm{ab}$ & $4.23 \mathrm{bc}$ & $4.69 \mathrm{bcd}$ & $0.73 \mathrm{c}$ & $1.67 \mathrm{abc}$ \\
S5 & $32.7 \mathrm{~d}$ & $46.7 \mathrm{bc}$ & $4.1 \mathrm{bc}$ & $3.31 \mathrm{~d}$ & $0.88 \mathrm{bc}$ & $1.09 \mathrm{c}$ \\
V10 & $60.3 \mathrm{ab}$ & $18.4 \mathrm{c}$ & $10.39 \mathrm{a}$ & $3.12 \mathrm{~d}$ & $1.83 \mathrm{a}$ & $1.12 \mathrm{c}$ \\
V5 & $15.2 \mathrm{~d}$ & $83.7 \mathrm{a}$ & $4.77 \mathrm{bc}$ & $7.01 \mathrm{a}$ & $1.46 \mathrm{ab}$ & $2.34 \mathrm{a}$ \\
MV10 & $30.4 \mathrm{~d}$ & $61.0 \mathrm{ab}$ & $6.10 \mathrm{~b}$ & $3.95 \mathrm{~cd}$ & $0.82 \mathrm{bc}$ & $1.68 \mathrm{abc}$ \\
MV5 & $38.4 \mathrm{bcd}$ & $57.5 \mathrm{ab}$ & $5.54 \mathrm{~b}$ & $4.72 \mathrm{bcd}$ & $1.13 \mathrm{bc}$ & $1.49 \mathrm{bc}$ \\
M10 & $35.0 \mathrm{~cd}$ & $69.6 \mathrm{ab}$ & $4.74 \mathrm{bc}$ & $4.98 \mathrm{bc}$ & $0.92 \mathrm{bc}$ & $1.87 \mathrm{ab}$ \\
M5 & $22.7 \mathrm{~d}$ & $54.1 \mathrm{ab}$ & $1.5 \mathrm{c}$ & $4.27 \mathrm{bcd}$ & $0.51 \mathrm{c}$ & $1.54 \mathrm{bc}$ \\
Chem & $76.0 \mathrm{a}$ & $53.0 \mathrm{ab}$ & $7.70 \mathrm{ab}$ & $5.68 \mathrm{ab}$ & $1.43 \mathrm{ab}$ & $1.99 \mathrm{ab}$ \\
C- & $57.6 \mathrm{ab}$ & $44.6 \mathrm{bc}$ & $5.89 \mathrm{~b}$ & $3.44 \mathrm{~cd}$ & $1.47 \mathrm{ab}$ & $1.38 \mathrm{bc}$ \\
\hline
\end{tabular}

Literals different in column means that there was a significant difference $(p<0.05)$

(a) (mg Rutine / mg fresh weight); (b) (mg gallic acid / fresh weight)

\subsection{Dendrogram}

In order to find a relationship between the composts applied to the soil and the characteristics presented by the lettuces grown in the presence of these composts, an exploratory analysis (JMP®PRO 13 for Windows software) was carried out considering all the vegetative variables evaluated (height, volume, number of leaves and leaf area per plant) and antioxidants (\% DPPH, polyphenols, and flavonoids), obtained depending on the treatments applied, the corresponding dendrogram is shown in Figure 3. 


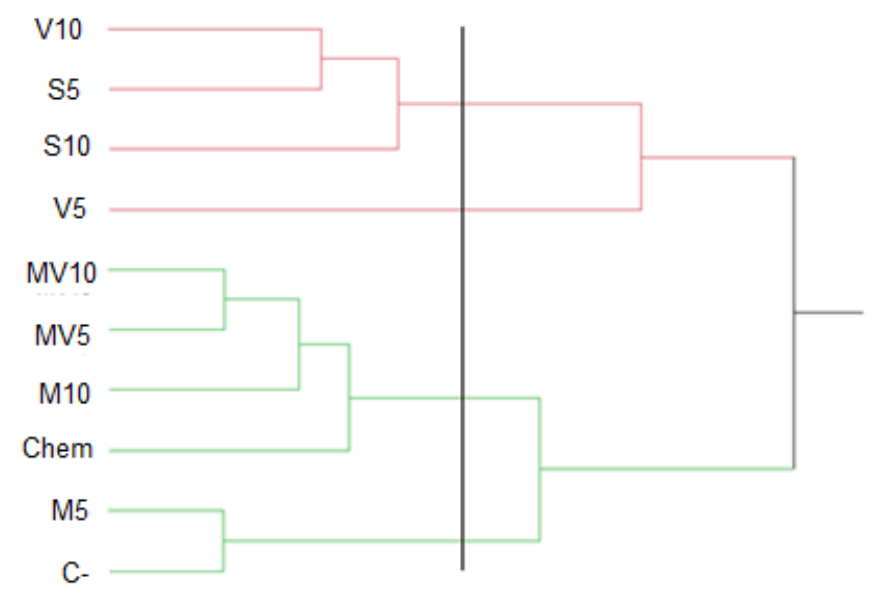

Fig. 3. Dendrogram of the lettuce vegetative variables and antioxidant content measured with composts V, S, M and MV applied at 5 and $10 \%$ and both controls C- and Chem.

Whit the variables evaluated, the dendrogram was obtained (Figure 3) in which there is clear separation between manure and vegetable waste composts. The results obtained in the cluster analysis, shows that the distance between the values obtained in the different treatments are grouped into two large groups, those made with manure, along with the controls and those of vegetable waste. The vertical line defines that four groups of treatments can be formed with similar results. It can be seen that in the first group, which were recorded the highest yields and values in the variables evaluated, is made up of composts prepared with vegetable residues (V10, S5 and S10), the V5 treatment is isolated but classified within the group of vegetable waste. The third group are composts in which manure has been used (MV10, MV5 and M10) these are grouped with the positive control (Chem), while in the last group there is the negative control (C-) and compost M5.

\subsection{Pearson Correlations}

The correlations of the variables evaluated in the different treatments were determined, considering the vegetative variables and the antioxidant content at week 8, which was the moment when the lettuces reached the appropriate height for the harvest (table 4).

Table 4 shows a high correlation $(\mathrm{p}<0.05 \%)$ between fresh weight, dry weight, and leaf area; there was a slight correlation between height and foliage volume with weights and leaf area. No correlation was found between the measured vegetative variables and antioxidants. There was a poor correlation between the \% of DPPH and the content of polyphenols and flavonoids ( $p<0.05 \%)$, which indicates that although the lettuce presented these compounds, they were not the only ones that contributed to the antioxidant activity quantified in the analysis of DPPH, as there is a slight correlation between the content of polyphenols and that of flavonoids. 
Table 4. Pearson correlation matrix between vegetative variables and antioxidant content.

\begin{tabular}{|c|c|c|c|c|c|c|c|c|}
\hline & Fresh weight & Dry weight & Foliar area & Height & Foliage Volume & DPPH & Poliphenols & Flavonoids \\
\hline Fresh weight & 1 & & & & & & & \\
\hline Dry weight & 0.988338 & 1 & & & & & & \\
\hline Foliar area & 0.937104 & 0.934111 & 1 & & & & & \\
\hline Height & 0.691819 & 0.698525 & 0.607625 & 1 & & & & \\
\hline Foliage volume & 0.518226 & 0.509627 & 0.654345 & 0.064591 & 1 & & & \\
\hline DPPH & 0.334086 & 0.433971 & 0.180937 & 0.494326 & -0.14459 & 1 & & \\
\hline Poliphenols & -0.05802 & 0.000784 & -0.33436 & 0.289985 & -0.52025 & 0.722528 & 1 & \\
\hline Flavonoids & 0.017255 & 0.081755 & -0.22226 & 0.405382 & -0.58309 & 0.725721 & 0.944468 & 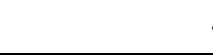 \\
\hline
\end{tabular}

\section{DISCUSSION}

Results give evidence that using composts is possible to achieve higher yields than fertilizing with urea. According to table 1 and figure 1, the compost with the highest macronutrient content was $S$, and plants fertilized with $S$ had the best growth, but all composts improve the growth of lettuce, except M5. This is probably due to the release of compost nutrients: $P$ has a role in physiological metabolic functions in plant tissues (Ojo and Obigbesen, 1999) and the $\mathrm{N}$ is the key nutrient for plant growth. Application of organic fertilizers probably enlarged nitrogen in the soil, this stimulates plant vegetative growth and increases leaf area, this increase causes a rise in the rate of plant photosynthesis; all these outcomes on higher leaf weight (Sanni, 2016). An EC value under the salinity limit value of $4 \mathrm{mS} / \mathrm{cm}$ is considered good for the fertilizers and it could indicate the stabilization and maturity of the composts (Liu et al., 2019), in this sense all composts were suitable to be used as fertilizers.

Besides the $\mathrm{pH}$ plays a very important role in the bioavailability of nutrients, some authors said that the optimum is $\mathrm{pH} 7$ because nutrients are more available; the compost $\mathrm{S}$ has the $\mathrm{pH}$ closest to the neutral value. The increase in $\mathrm{pH}$ in one unit decreases the concentration of $\mathrm{Fe}$ one thousand times and one hundred times the concentration of $\mathrm{Mn}^{+2}$ (Vale et al., 1997). The negative effect observed in compost $\mathrm{M}$ may be due to its $\mathrm{pH}$ value of 9.3 , this is the most alkaline compost and the availability of $\mathrm{N}$ is significantly reduced at $\mathrm{pH}>8.2$; Cerozi and Fitzsimmons (2016) observed that an elevated $\mathrm{pH}$ level could decrease the availability of nutrients in plants. For this reason, compost $\mathrm{M}$ applied at $5 \%$ had no significant effect on the growth of lettuce because of the amount of nutrients available was reduced. With all of the composts, except M5, the lettuces grew in a greater proportion than in the unfertilized soil (C-).

The results are in agreement with the reported benefits of the composts, as the compost acts as a storage and source of nutrients in the soil (Jong-Ho, 2000), after ammonification and nitrification, the compost is converted into essential elements 
that are utilized by the plants (Meng et al., 2017). In addition, the organic matter influences the degree of aggregation and stability of soil aggregates, decreasing their density and increasing their porosity (Anikwe, 2000). Composts often avoid the movement of nutrients, in this way, the availability of minerals depends on its interaction with media and microorganisms (Santos et al., 2016). An increase in soil respiration after organic amendments was found by several authors and indicates an increase in microbial activity which is responsible of the nutrients release from the organic matter added to the soil (Morra et al., 2010)

Composts $\mathrm{S}$ and $\mathrm{V}$ favored the growth of lettuce plants more than those prepared with manure (MV and $M$ ). These results suggest that the final properties and the effect of the composts as an organic fertilizer, depends on the nature of the waste used for the composting process, in the case of lettuce cultivation, it was better using vegetable waste. The use of compost where manure was used (M) did not favor the growth of lettuce plants; however, using the compost MV, better results were obtained than using mineral fertilization with urea.

Some authors have also shown that the addition of compost in lettuce cultivation increases its growth, such as increasing the length, diameter, the number of leaves, fresh and dry weight and yield of lettuce (Kapoulas et al., 2017; Hernández et al., 2016; Khazei et al., 2013; Maqueda et al., 2011; Coria-Cayupan et al., 2009; Magkos et al., 2003). Besides the quality of lettuce in response to compost amendments has been reported, with substantial proportions of studies showing either lower or higher nutrients contents compared with the conventional field (Santos et al., 2016).

Most of the composts improved the antioxidants content at week 8 compared with week 6; it was reported by Lizarazo et al. (2010) that antioxidants content in tissues of edible leaves, like lettuce increased with tissue age. There was no more production of antioxidants, polyphenols, and flavonoids using composts compared with Chem, it is conclusive that the addition of composts did not have an effect on the increase in the production of antioxidants compared to the use of urea, but with some of the composts increased DPPH at week 8 compared with treatment C-. There was no difference in the antioxidants measured applying composts made with vegetable waste or made with manure, contrary to the observed in the vegetative variables.

There are contradictory results reported about the relationship on antioxidants production and addition of composts, for example, Santos (2016) observed that the cultivation of lettuce in the presence of compost enriched it in bioactive compounds, compared to the use of mineral fertilizer. However, Sofo et al. (2016) found that the cultivation of lettuce with traditional fertilization increased the content of phenolic acids compared to organic treatment; this may be due to stress conditions in terms of mineral deficiency; while there were no differences in flavonoid content between both types of fertilization. Kapoulas et al. (2017) reported that there was no difference in the total polyphenol content or the total antioxidants, in lettuce grown under traditional and organic fertilization scheme. 
Durazzo et al. (2014) found no differences in the quantification of some phenolic compounds in lettuces grown organically, and under a conventional system in the period of July, but they found differences in lettuce grown in September. Galvez et al. (2005) evaluated various composts prepared with different residues to determine their effect on the production and antioxidant content of lettuce, and found an increase in phenolic compounds and high yield in lettuces grown with chestnut-based compost, besides an increase in phenolics but reduced production using compost prepared with white grapes.

It has been reported that there are several factors involved in the synthesis of antioxidants. Galieni et al. (2015) reported that nutrition, environment stress, and agronomic conditions affect the production of antioxidants, for example: A nitrogen deficiency induces the accumulation of ascorbic acid, flavonoids, and flavonoids in arabidopsis and tomato. Nitrogen availability seemed to reduce total polyphenols and antioxidant activity (Coria-Cayupan et al., 2009). The phenolic amount in lettuce differs in response to cultivars (Llorach et al., 2008). Outdoor or indoor growing cultivation also affects as well as environmental stress (Zhao et al.,2009). Drought improves phenolics and antioxidant capacity (Oh et al., 2010). Lizarazo et al. (2010) found that the content of tocopherol in vegetables can be notably enhanced (or reduced) by simply selecting the appropriate harvesting time and/or by manipulating the environmental conditions during the growth period.

For the results of this work can be state that there was a significant difference between the lettuces that grew fertilized with the different composts compared with soil without fertilizing (C-) or fertilized with urea (Chem). The measurements of height, fresh and dry weight, foliage volume and leaf area per plant, showed greater growth in the presence of the composts. With composts prepared with plant residues ( $\mathrm{V}$ and $\mathrm{S})$, greater growth was obtained than those prepared with manure ( $\mathrm{M}$ and $\mathrm{MV}$ ); the type of material used to prepare the composts, had a significant effect on the crop, in the case of lettuce is recommended compost prepared with vegetable residues. The content of antioxidants in lettuces fertilized with any of the composts, compared with Chem was similar; however, with some of the treatments using composts were registered higher DPPH values than C-. The use of composts represents many benefits, vegetable waste or manure could be used to produce organic fertilizers, which improve plant growth compared with fertilization with urea.

\section{ACKNOWLEDGEMENTS}

Authors want to thank the Consejo Nacional de Ciencia y Tecnologia for the fellowships granted to Joseph I. Hernández-Rivadeneyra.

\section{CONFLICT OF INTEREST}

The authors have no conflicts of interest to declare. 


\section{REFERENCES}

Anikwe M. A. N. 2000. Amelioration of a heavy clayloam with rice husk dust and its effect on soil physical properties and maize yield. Bioresourse Technology. 74: 169-177.

Bolaños G. M. A., Paz P. F, Cruz G. C. O., Argumedo E. J. A., Romero B. V. M. \& de la Cruz C. J. C. 2016. Mapa de erosión de los suelos de México y posibles implicaciones en el almacenamiento de carbono orgánico del suelo. Terra Latinoamericana. 34: 271-288.

Cerozi B. \& Fitzsimmons K. (2016). The effect of pH on phosphorus availability and speciation in an aquaponics nutrient solution. Bioresource Technology. 219: 778781.

Coria-Cayupan J. C., Sanchez Y. S., \& Nazareno M. A. 2009. Variations in bioactive subtance content and crop yields of lettuce (Lactuca sativa $L$ ) cultivated in soils with different fertilization treatments. Journal of Agricultural and Food Chemistry. 57: 10122-10129.

Cui K., Luo X., Xu K. \& Ven M. R. 2004. Review Role of oxidative stress in neurodegeneration: recent developments in assay methods for oxidative stress and nutraceutical antioxidants. Progress in Neuro-Psychopharmacology \& Biological Psychiatry. 28(5): 771-99.

Durazzo A., Azzini E., Lazzé M. C., Raguzzini A., Pizzala R., Lara G. M \& Maiani G. 2014. Antioxidants in Italian Head Lettuce (Lactuca sativa var. capitata L.) Grown in Organic and Conventional Systems under Greenhouse Conditions. Journal of Food Biochemistry. 38(1): 56-61.

Floegel A., Dae-Ok K., Sang-Jin Ch., Sung I. K. \& Ock K. Ch. 2011. Comparison of ABTS/DPPH assays to measure antioxidant capacity in popular antioxidant-rich US foods. Journal of Food Compostion and Analysis. 24: 1043-1048.

Gálvez M., Martín-Cordero C., Houghton P. J. \& Ayuso M. J. 2005. Antioxidant activity of metanol extract obtained from Plantago species. Journal of Agricultural and Food Chemistry. 53: 1927-1933.

Hartwig V.G., Brumovsky L.A., Fretes R.A. \& Sánchez L.B. 2012. A novel procedure to measure the antioxidant capacity of yerba maté extracts. Food Science and Technology (Campinas). 32(1): 126-133.

Hernández T., Chocano C., Moreno J. L. \& García C. 2016. Use of compost as an alternative to conventional mineral fertilizers in intensive lettuce (Lactuca sativa L.) crops-Effects on soil and plant. Soil \& Tillage Research. 160:14-22. 
Jong-Ho S. 2000. Use of hairy vetch green manure as nitrogen fertilizer for corn food. Korean Journal of Crop Science. 45(5): 294-299.

Ismaiel M., El-Ayouty Y. \& Piercey-Normore M. 2016. Role of pH on antioxidants production by spirulina (Arthrospira) plantesis. Brazilian Journal of Microbiology. 47(2): 298-304.

Kapoulas N., Koukounaras A. \& Ilic Z. S. 2017. Nutritional quality of lettuce and onion as companion plants from organic and conventional production in north Greece. Scientia Horticulturae. 219: 310-318.

Khazei I., Salehi R., Kashi A. \& Mirjalil S. 2013. Improvement of lettuce growth and yield with spacing, mulching and organic fertilizer. International Journal of Agriculture and Crop Sciences. 6(16): 1137-1143.

Li H., Feng W., He X., Zhu P., Gao H., Sun N. \& Xu M. 2017. Chemical fertilizers could be completely replaced by manure to maintain high maize yield and soil organic carbon. Journal of Integrative Agriculture. 16(4): 937-946.

Liu H., Qiu N., Ding H. \& Yao R. 2008. Polyphenols contents and antioxidant capacity of 68 Chinese herbals suitable for medical or food uses. Food Research International 41: 363-370

Liu P., Kallio H. \& Yang B. 2011. Phenolic compounds in hawthorn (Crataegus grayana) fruits and leaves and changes during fruits ripening. Journal of Agricultural and Food Chemistry. 59(20): 11141-11149.

Liu T., Meijing W., Kumar M. A., ChenH., Kumar A. S., Duan T. \& Zhang Z. 2020. Measurement of cow manure compost toxicity and maturity based on weed seed germination, Journal of Cleaner Production. 245(1): 118894-118899.

Lizarazo K., Fernández-Marin B., Becerril J. \& García-Plazaola J. 2010. Ageing and irradiance enhance vitamin $\mathrm{E}$ content in green edible tissues from crop plants. Journal of the Science of Food and Agriculture. 90(12):1994-1999.

Llorach, R. \& Martínez-Sánchez A. 2008. Characterisation of polyphenols and antioxidant properties of five lettuce varieties and escarole. Food Chemistry.108: 1028-1038.

Magkos F., Arvaniti F. \& Zampelas A. 2003. Organic food: nutritious food or food for thought, a review of evidence. International Journal of Food Science and Nutrition. 54: 357-371.

Majewska M., Skrzycki M., Podsiad G., \& Czeczot H. 2011. Evaluation Of Antioxidant Potential Of Flavonoids: An In Vitro Study. Acta Poloniae Pharmaceutica - Drug Research. 68(4): 611-615. 
Maqueda, C., Herencia J. F., Ruiz J. C. \& Hidalgo M. F. 2011. Organic and mineral fertilization effects on DTPA-extractable $\mathrm{Fe}, \mathrm{Cu}, \mathrm{Mn}$ and $\mathrm{Zn}$ and their concentration in the edible portion of crops. Journal of Agricultural Science. 149: 461-472.

Morra L., Pagano L., lovieno P., Baldantoni D. \& Alfani A. 2010. Soil and vegetable crop response to addition of different levels of municipal waste compost under Mediterranean greenhouse conditions Agronomy for Sustainable Development. 30: 701-709.

NADF-020-AMBT-2011. 2012. Norma ambiental para el Distrito Federal NADF020-AMBT-2011, que establece los requerimientos mínimos para la producción de composta a partir de la fracción orgánica de los residuos sólidos urbanos, agrícolas, pecuarios y forestales, así como las especificaciones mínimas de calidad de la composta producida y/o distribuida en el Distrito Federal.

Nicolle C., Cardinault N., Gueux E., Jaffrelo L., Rock E., Mazur A., Amouroux P., \& Rémésy C. 2004. Health effect of vegetable-based diet: lettuce consumption improves cholesterol metabolism and antioxidant status in the rat. Clinical Nutrition. 23(4): 605-614.

NMX-AA-180-SCFI-2018. Norma Oficial Mexicana que establece los métodos y procedimientos para el tratamiento aerobio de la fracción orgánica de los residuos sólidos urbanos y de manejo especial, así como la información comercial y de sus parámetros de calidad de los productos finales.

NOM-021-SEMARNAT-2000. Norma Oficial Mexicana que establece las especificaciones de fertilidad, salinidad y clasificación de suelos, estudio, muestreo y análisis.

Oh M.M., Carey E.E. \& Rajashekar C.B. 2010. Regulated water deficits improve phytochemical concentration in lettuce. Journal of the American Society for Horticultural Science. 135: 223-229.

Ojo O. D. \& Obigbesen G. O. 1999. Optimum rate for grain Amaranth production. Proceedings of the 25th annual conference of soil science society of Nigeria. Benin 192-196.

Ollúa R. T., Logegaray V. R. \& Chiesa A. 2016. concentración de nitratos en dos tipos comerciales de lechuga (lactuca sativa I.) cultivadas con distintas fuentes nitrogenadas The Chilean Journal of Agricultural \& Animal Sciences. 32(3): 94101.

Onwosi Ch. O., Igbokwe V. C., Odimba N. J., Eke I. E., Nwankwoala M. A, Iroh I. N. \& Ezeogu L. I. 2017. Review. Composting technology in waste stabilization: On the methods, challenges and future prospects. Journal of Environmental Management 190: 140-157- 
Pandey K. B. \& Rizvi S. I. 2009. Plant polyphenols as dietary antioxidants in human health and disease. Oxidative Medicine and Cellular Longevity. 2: 270-278.

Pimentel D. \& Burgess M. 2013. Soil Erosion Threatens Food Production. Agriculture. 3(3): 443-463.

Rouphael Y. Kyriacou M. C., Petropoulos S. A., S de Pascale, Colla C. 2018. Improving vegetable quality in controlled environments. Scientia Horticulturae. 234: 275-289.

Ruiz M. F., Sosa C., Carrillo C., De Valls J., Escalona L., Aular \& Figueroa R. 2010. Comparación de procedimientos para analizar fertilizantes potásicos. Venesuelos. 18(1): 35-43.

Sanni, K. O. 2016. Effect of compost, cow dung and NPK 15-15-15 fertilizer on growth and yield performance of Amaranth (Amaranthus hybridus). International Journal of Advances in Scientific Research. 2(03): 076-082.

Santos B., Saavedra O., Duárez T., Coello A., Solaz C. 2014. ¿Cómo tomar muestras de suelos?, Cultivos de medianías. Agro Cabildo, Cabildo de Tenerife.

Santos F. T., Goufo P., Santos C., Botelho D., Fonseca J., Queirós A., Costa M. S. $S$ \& Trindale H. 2016. Comparison of five agro-industrial waste-based composts as growing media lettuce: Effect on yield, phenolic compounds and vitamin C. Food Chemistry. 209: 293-301.

Sofo A., Lundegardh B., Martensson A., Manfrac M., Pepe G., Sommella E., De Nisco M., Tenore G.C., Campiglia P, Scopa A. 2016. Different agronomic and fertilization systems affect polyphenolic profile, antioxidant capacity and mineral compositicon of lettuce. Scientia Horticulturae 204: 106-115.

Tiquia S. M. \& Tam N. F. Y. 1998. Elimination of phytotoxicity during cocomposting of spent pig- manure sawdust litter and pig sludge. Bioresourse Technology. 65: 43-49.

Vale, F. R., Guilherme L. R. G., Guedes G. A. de A., Furtini N. A. E.1997. Fertilidade do solo: dinámica e disponibilidade dos nutrientes de plantas. Lavras: UFLA/FAEPE. 171.

Valenzuela S. R., Jiménez V. J., García G. R., Betancourt M. N. D., Lozoya M. R., Almaráz C. D. \& Morán M. J. 2019. Evaluación de la actividad antioxidante de Cnidoscolus chayamansa (chaya), Euphorbia prostrata (hierba de la golondrina) y Jatropha dioica (sangre de drago) en ratas Wistar inducidas a hiperglicemia. International Journal of Morphology. 37(1): 36-42.

Wilson M. H. \& Lovell L. S. 2016. Agroforestry-The Next Step in Sustainable and Resilient Agriculture. Sustainability. 8: 574-589. 
Zhao X., Nechols J. R., Williams K. A., Wang W. \& Carey E. E. 2009. Comparison of phenolic acids in organically and conventionally grown pac choi (Brassica rapa L. chinensis). Journal of the Science of Food and Agriculture. 89: 940-946. 